\title{
Tragedi Keluarga Nuh dan Pengabaian Anggota Keluarga: Tafsir Kejadian 9:18-29
}

\author{
Noah's Family Tragedy and Family Members Abandonment:
}

A Commentary on Genesis 9:18-29

\begin{abstract}
Author:
- Firman Panjaitan ${ }^{1}$

- Dwi Ratna

Kusumaningdyah²

\section{Affiliation:}

${ }^{1}$ Sekolah Tinggi Teologi Tawangmangu

panjaitan.firman@gmail.com

${ }^{2}$ Sekolah Tinggi Teologi

Tawangmangu

Dates:

Submitted:

15 June 2021

Accepted:

21 October 2021

Published:

12 November 2021

DOI:
\end{abstract}

10.46494/psc.v17i2.141

\section{Copyright:}

(C) 2021. The Authors. Licensee: This work is licensed under the Creative Commons Attribution-ShareAlike 4.0 International License.

\begin{abstract}
The primary condition of a blessed family is to live in moral holiness and mutual respect for one another. When concern for family members is neglected, what happens is a tragedy that divides the family. Likewise with Noah's family, unable to maintain the integrity of the family due to the dishonor of Ham's behavior. Blessings and curses follow this attitude. This study explores the meaning of Genesis 9:18-29 using the Narrative Method, which is then relevant to the present. This study proves that respect for each family member will bring blessings to the next generation, and vice versa, that disrespect brings division to the family and its descendants..

[Syarat utama dari keluarga yang menjadi berkat adalah hidup dalam kekudusan moral dan saling menghormati satu sama lain. Ketika penghormatan terhadap anggota keluarga diabaikan, maka yang terjadi adalah tragedi yang memecah belah keluarga tersebut. Demikian juga dengan keluarga Nuh, tidak dapat memertahankan keutuhan keluarga akibat ketidakhormatan perilaku Ham. Berkat dan kutuk mengikuti sikap tersebut. Dengan menggunakan metode narasi, penelitian ini mengupas makna terhadap kisah Kejadian 9:18-29, yang kemudian direlevansikan ke masa kini. Penelitian ini membuktikan bahwa penghormatan kepada setiap anggota keluarga akan mendatangkan berkat bagi keturunan selanjutnya, demikian juga sebaliknya, bahwa ketiadaan hormat mendatangkan perpecahan bagi keluarga dan keturunannya.]
\end{abstract}

Research Contribution: Penelitian ini berkontribusi dalam pengembangan ilmu psikologi keluarga yang beririsan dengan konsep teologis.

Keywords: family, Noach, genesis, tragedy, Old Testament

\section{Pendahuluan}

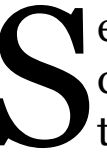

ebuah satire seringkali terjadi dalam kehidupan berkeluarga yang ditunjukkan melalui pembedaan sikap dan tindakan orang tua terhadap anak-anaknya sendiri. Beberapa penelitian mengungkapkan bahwa ketika seorang anak mendapat perlakuan yang berbeda dari orangtuanya, akan membuat anak tersebut tumbuh tanpa memiliki ikatan lahir-batin dengan saudara-saudaranya. Hal ini mengawalil hancuran hubungan keluarga di masa depan. 
Pembedaan perlakuan terhadap anak inilah yang menjadi masalah utama dalam keluarga Nuh setelah peristiwa air bah, yang pada akhirnya membawa 'perpecahan' di antara anak-anak Nuh. ${ }^{1}$

Setelah peristiwa air bah berlalu yang ditandai dengan adanya perjanjian Allah dengan Nuh, muncul harapan akan adanya kehidupan yang lebih baik jika dibandingkan dengan zaman sebelum air bah terjadi. ${ }^{2}$ Melalui air bah, kekerasan dan kejahatan manusia telah dihapuskan. Dari satu keluarga, yaitu keluarga Nuh yang diselamatkan oleh Allah, dibayangkan akan dimulai sebuah zaman baru yang tidak lagi diwarnai dengan kejahatan dan kekerasan. 3 Namun bayangan ini dapat dikatakan hanya sebuah ilusi saja, karena bagi para penulis kisah-kisah dalam kitab Kejadian hal semacam itu tidak harus terjadi. Hal ini bisa dilihat dalam percakapan yang berlangsung antara Allah dan Nuh (Kej. 8:15-9:17), di mana dengan jelas Allah mengungkapkan bahwa akan terjadi berbagai pengulangan pelanggaran seperti yang terjadi pada zaman sebelum air bah. Hal itu diperlihatkan melalui ungkapan tentang pengakuan dan penerimaan Allah akan keberadaan manusia yang bukan hanya memiliki hal-hal yang baik dalam dirinya, namun juga memiliki kecenderungan untuk berbuat jahat.

Demikian pula tentang pola pembalasan yang masih mungkin terulang kembali dalam hubungan antar manusia. Dengan demikian keretakan-keretakan hubungan antar manusia

\footnotetext{
${ }^{1}$ Sariwandi Syahroni, "Peranan Orang Tua Dan Sekolah Dalam Pengembangan Karakter Anak Didik,"

Intelektualita 6, no. 1 (2017): 13,

https://doi.org/10.19109/intelektualita.v6i1.1298; Lutfi Rachman, "Peran Orang Tua Terhadap Anak Perspektif Pendidikan Islam," Jurnal Pendidikan Islam 7, no. 02 (2017): 1-12, https://doi.org/10.38073/jpi.v7io2.41; Leni Novita, "Pengaruh Kualitas Lingkungan Keluarga Dan Sekolah Terhadap Karakter Remaja Perdesaan," Thesis (Pascasarjana Institut Pertanian Bogor, 2016), 21-23.

${ }^{2}$ Sonny Eli Zaluchu, Pentateuch - Narasi Narasi Utama Kitab Musa, 1st ed. (Semarang: Golden Gate Publishing, 2020), 58-65.
}

masih mungkin terjadi pada zaman sesudah air bah. 4

Dengan demikian dapat digambarkan bahwa sesungguhnya peristiwa air bah hendak menggambarkan tindakan Allah untuk memulai sebuah kehidupan baru, yang diwakili oleh keluarga Nuh, namun bukan berarti bahwa kejahatan dan pelanggaran-pelanggaran sirna dari muka bumi. Secara realistik Allah berkata, bahwa kejahatan dan pelanggaran akan terus terjadi, namun minimal manusia bisa belajar bahwa kejahatan dan pelanggaran hanya mendatangkan kesengsaraan bagi hidup, bukan kebahagiaan.5 Penelitian ini hendak memaparkan tentang kejadian yang terjadi dengan keluarga Nuh setelah melewati masa seleksi melalui peristiwa air bah. Sebagai keluarga yang telah terseleksi, apakah Nuh dan keluarganya akan menjaga kekudusan moral seperti yang diharapkan Allah kepada mereka atau justru perkataan Allah yang dijelaskan oleh narator yang mengatakan bahwa akan selalu terjadi kejahatan dan pelanggaran pada episode-episode kehidupan manusia setelah peristiwa air bah yang akan benar-benar terjadi? Dalam penelitian ini pun hendak diungkapkan apa yang akan terjadi terhadap keluarga yang telah dipilih dan terseleksi ketika salah seorang anggota keluarga tersebut tidak bisa menjaga kekudusan moral. Dalam pengertian, bahwa keterpilihan sebuah keluarga tidak menjamin bahwa keluarga tersebut akan terus mendatangkan berkat bagi kehidupan, terutama ketika salah seorang anggota keluarga

3 Bruce D. Friedman, "Noah: A Story of Peacebuilding, Nonviolence, Reconciliation, and Healing," Journal of Religion and Spirituality in Social Work 38, no. 4 (2019): 401-14, https://doi.org/10.1080/15426432.2019.1672609. 4 Ma Maricel S. Ibita, "The Great Flood in Genesis 6-9: An Ecological Reading of the J and P Traditions," Biblical Theology Bulletin 50, no. 2 (2020): 68-76, https://doi.org/10.1177/0146107920913791.

5 Stanislaus Surip, "Kelola Bumi Peduli Ekologi Menurut Kej 1:28," Studia Philosophica et Theologica 20, no. 1 (2020): 80-99,

https://doi.org/10.35312/spet.v20i1.190. 
tidak dapat menjaga kekudusan moral. ${ }^{6}$ Penelitian ini pun akan membuktikan bahwa berkat dan menjadi berkat senantiasa berkelindan dengan hidup kudus, dan inilah yang mendorong penulis untuk meneliti dan memahami lebih dalam kisah dalam Kejadian 9:18-29.

\section{Metode}

Secara umum penelitian ini akan menggunakan metode kualitatif, yaitu sebuah prosedur riset yang memanfaatkan data deskriptif berupa kata-kata tertulis yang diperoleh melalui berbagai sumber dan referensi yang terkait dengan objek penelitian. 7 Adapun pendekatan yang dilakukan dalam memahami teks Kejadian 9:18-27 adalah pendekatan naratif, yaitu sebuah upaya untuk memahami teks Alkitab dengan berfokus pada apresiasi terhadap nilai estetika yang terdapat dalam teks tersebut. Pendekatan naratif ini digunakan dengan tujuan agar maksud penulis dalam teks dapat ditangkap. Namun pendekatan naratif tidak senantiasa memerhatikan secara detil setiap bagian yang menjadi latar belakang sejarah, konteks/situasi zaman (sitz im leben/setting in life) maupun hal-hal yang menjadi latar belakang teks, seperti halnya pendekatan literer. ${ }^{8}$ Meskipun pendekatan naratif kurang memerhatikan terjemahan dari bahasa asli, namun dalam penelitian ini penulis akan berangkat dari upaya penerjemahan dari bahasa asli (Ibrani) dengan pemahaman bahwa langkah pertama dari sebuah tafsir adalah terjemahan dan bertujuan untuk menangkap pesan utama dalam teks dapat dijabarkan terlebih dahulu melalui hasil penerjemahan. 9 Langkah selanjutnya penulis akan menghadirkan

\footnotetext{
${ }^{6}$ Widhi Arief Nugroho, "Peranan Pendidikan Keluarga Tentang Kekudusan Hidup Menurut Roma 12:1-2," FIDEI: Jurnal Teologi Sistematika Dan Praktika 1, no. 2 (2018): 185-98,

https://doi.org/10.34081/fidei.v1i2.16.

7 Ahmad Rijali, “Analisis Data Kualitatif," Alhadharah: Jurnal Ilmu Dakwah 17, no. 33 (2019): 81-95,

https://doi.org/10.18592/alhadharah.v17i33.2374.
}

karakteristik dan penokohan yang ada dalam Kejadian 9:18-29 agar tercipta 'benang merah' antara kisah dan keterkaitan para tokoh. Terakhir penulis akan menafsir berdasarkan teks yang telah diterjemahkan, dengan bantuan buku dan referensi yang mendukung penelitian ini, dan kemudian merelevansikan kisah tersebut dengan masa kini.

\section{Pembahasan}

\section{Terjemahan Teks Kejadian 9:18-29}

Sebagai langkah awal tafsir, terlebih dahulu dihadirkan hasil terjemahan yang penulis lakukan terhadap teks bahasa asli Kejadian 1:18-29. ${ }^{10}$ Karena jenis pendekatan ini adalah narasi, maka dengan sengaja penulis akan menghilangkan penomoran ayat, agar teks Kejadian 9:18-29 dapat dirangkai dalam satu bentuk narasi yang utuh. Berikut hasil terjemahan tersebut: Adapun anak-anak Nuh yang keluar dari bahtera itu adalah Sem, Ham dan Yafet, dan Ham, dialah bapak Kanaan. Inilah ketiga anak-anak Nuh dan dari merekalah tersebar penduduk seluruh bumi itu. Nuh menjadi petani pertama dan ia membuat kebun anggur. Ia minum dari anggur itu, lalu ia menjadi mabuk dan ia telanjang di kemahnya. Ham, bapak Kanaan melihat ketelanjangan ayahnya lalu menceritakan kepada kedua saudaranya (laki-laki) di luar. Sem dan yafet mengambil pakaian dan meletakkan di atas kedua pundak mereka, lalu mereka berjalan mundur, menutup ketelanjangan ayah mereka dan wajah-wajah mereka dipalingkan sehingga ketelanjangan ayah mereka tidak mereka lihat. Kemudian Nuh sadar dari mabuknya dan ia mengetahui apa yang dilakukan anak laki-lakinya yang termuda kepadanya. Dan Ia (Nuh) berkata, "Terkutuklah Kanaan, ia akan menjadi hamba dari hamba-hamba bagi saudara-saudaranya." Ia berkata,"Terpujilah TUHAN, Allah Sem dan biarlah Kanaan menjadi hambanya. Allah akan

\footnotetext{
${ }^{8}$ Herry Susanto, "The Church as God's People and The Patner of State," Jurnal Jaffray 17, no. 1 (2019): 35-56. 9 Don L Fisher, Hermeneutik Interpreting The Bible (Malang: Gandum Mas, 2016), 91.

10 Biblia 001-VT, Biblia Hebraica (Stuttgart: Deutsche Bibelgesellschaft, 1990), 13-14.
} 
memperbesar Yafet dan membiarkan tinggal di kemah Sem dan Ia membiarkan Kanaan menjadi hambanya" Nuh hidup 350 tahun lagi sesudah air bah. Seluruh hari-hari Nuh adalah 950 tahun, lalu ia mati.

\section{Karakteristik dan Penokohan}

Beberapa karakteristik yang bisa dihadirkan untuk menggambarkan beberapa tokoh yang terlibat langsung dalam teks Kejadian 9:18-29 adalah:

1. Nuh, yaitu seorang tokoh utama yang dihadirkan oleh narrator. Tokoh ini digambarkan sebagai sosok yang reaktif, arogan dan egosentris (cenderung tidak peduli terhadap lingkungan). Hal ini terlihat dari cara Nuh bersikap, yaitu mabuk (tidak peduli terhadap lingkungan dan keluarganya). Sikap reaktif dan arogan ditunjukkan dengan langsung mengutuki Ham, tanpa klarifikasi dan memahami letak masalah yang sebenarnya. ${ }^{11}$ Meskipun Nuh adalah tokoh utama, tetapi perannya lebih terlihat sebagai sosok antagonis, karena Nuh yang memulai terjadinya perpecahan dalam keluarga akibat pembedaan sikap yang diberikan kepada ketiga anaknya.

2. Ham, yaitu anak penengah Nuh (jika diperhatikan dalam urutan nama anak-anak Nuh di pembukaan kisah). Ham digambarkan sebagai sosok yang terus terang, bahkan cenderung 'kurang ajar'. Hal ini terlihat dalam peristiwa ketika ia melihat ayahnya telanjang, lalu menceritakan ketelanjangan ayahnya kepada kedua saudaranya. Akibat sikapnya tersebut, Ham mendapat kutukan dari ayahnya, yaitu menjadi budak bagi kedua saudaranya (Sem dan Yafet). ${ }^{12}$

\footnotetext{
${ }^{11}$ Jennifer Knust, "Who's Afraid of Canaan's Curse? Genesis 9:18-29 and the Challenge of Reparative Reading," Biblical Interpretation 22, no. 4-5 (2014): 390-92, https://doi.org/10.1163/15685152-02245po2. 12 Mohamed Shahid Mathee, "Curse Motives in the 'Curse of Ham' Narrative: Land for Yahweh'S Landless People?,” Journal for Semitics 25, no. 2 (2017): 726-47, https://doi.org/10.25159/1013-8471/2554.
}

3. Sem dan Yafet, yaitu anak pertama dan terakhir Nuh. Keduanya digambarkan sebagai anak yang sopan, namun cenderung pengadu. Dari mereka berdualah Nuh mengetahui tindakan Ham ketika Nuh sedang mabuk, dan atas laporan kedua anaknya tersebut Nuh memarahi dan mengutuki Ham yang adalah anaknya sendiri. Kebalikan dari tindakan Nuh kepada Ham, kepada Sem dan Yafet diberikan berkat yang luar biasa. Kemungkinan, kemarahan Nuh kepada Ham, adalah akibat pengaduan Sem dan Yafet yang bersifat menjelek-jelekkan Ham dan memuji diri mereka berdua sebagai anak yang berbakti. Inilah yang mendorong Nuh mengeluarkan berkat dan sekaligus kutuk dalam waktu yang bersamaan. ${ }^{13}$

\section{Struktur Teks}

Jika mengikuti teori sumber, maka Kejadian 9:18-27 berasal dari sumber Y (Yahwis) dan Kejadian 9:28-29 berasal dari sumber $\mathrm{P}$ (Priester Codex). Karena keduanya dapat dipandang sebagai sebuah kisah yang utuh, maka kedua naskah yang berasal dari dua sumber berbeda ini dapat disatukan. Jika dilihat narasi Kejadian 9:18-29 secara utuh, maka bagian ini merupakan akhir dari kisah air bah yang sekaligus menghantar pembaca untuk memahami penyebaran penduduk dari keturunan Nuh, yang diungkapkan dalam bagian selanjutnya, yaitu Kejadian 10-11.14 Penulis akan membagi narasi Kejadian 9:18-29 menjadi empat episode, yaitu:

a. Episode 1: Kejadian 9:18-19. Bagian ini berisi pendahuluan yang mengungkapkan bahwa asal-usul penduduk yang tersebar di seluruh bumi adalah dari keturunan Nuh.

\footnotetext{
13 David Frankel, "Noah's Drunkenness and the Curse of Canaan: A New Approach,” Journal of Biblical

Literature 140, no. 1 (2021): 49-68,

https://doi.org/10.15699/JBL.1401.2021.3.

14 Tremper Longman III and David E. Garland, "The

Expositor's Bible Commentary,” in The Expositor's Bible Commentary Revised Edition, 2007, 117.
} 
b. Episode 2: Kejadian 9:20-24. Dalam episode ini digambarkan tentang masalah yang muncul dalam keluarga Nuh, setelah Nuh menjadi petani anggur.

c. Episode 3: Kejadian 9:25-27. Episode ini mengisahkan mengenai kutuk dan berkat bagi keturunan Nuh sehingga Kanaan (Ham) menjadi hamba bagi keturunan Sem dan Yafet.

d. Episode 4: Kejadian 9:28-29. Episode ini merupakan penjelasan akhir tentang Nuh, sekaligus menutup cerita yang diawali dari Kejadian 5:32.

\section{Tafsir}

\section{Episode 1: Kejadian 9:18-19}

Episode ini diawali dengan penjelasan narator tentang anak-anak Nuh yang keluar dari bahtera, yaitu Sem, Ham dan Yafet. Penjelasan ini berbeda dengan penjelasan yang ada dalam Kej.8:18 yang menyebut tentang istri-istri mereka juga. ${ }^{15}$ Lempp menegaskan perbedaan informasi ini dengan argumentasi bahwa mereka semuanya masih bertempat tinggal dalam kemah Nuh sehingga mereka dianggap sebagai anak muda yang belum kawin. ${ }^{16}$ Penulis mengakui adanya perbedaan informasi, namun tidak berarti bahwa mereka masih lajang seperti yang diungkapkan oleh Lempp, karena narator memang tidak bermaksud menguraikan secara rinci siapasiapa yang keluar dari bahtera, namun mau menjelaskan tentang asal-usul penyebaran penduduk. ${ }^{17}$ Selain itu kalimat, "tinggal bersama ayahnya" tidak selalu harus dipahami sebagai belum kawin, karena pada zaman Nuh, keluarga memiliki arti yang luas, termasuk

15 Thomas M. Bolin, "Noah's Curse: The Biblical Justification of American Slavery," History: Reviews of New Books 31, no. 2 (2003): 61,

https://doi.org/10.1080/03612759.2003.10527895.

${ }^{16}$ Longman III and Garland, "The Expositor's Bible Commentary."

${ }_{17}$ E.G. Singgih, Dari Eden Ke Babel: Sebuah Tafsir Kejadian 1-11 (Yogyakarta: PPST UKDW, 2011), 89-91. 18 Milton Eng, New International Dictionary of Old Testament Theology and Exegesis, Journal of the menantu yang tinggal bersama-sama. Disinyalir bahwa Nuh dan seluruh keluarganya tinggal dalam kemah yang biasa digunakan oleh para nomad dan biasanya kemah untuk para perempuan terpisah dari laki-laki, kemah para istri berdekatan dengan kemah suaminya. ${ }^{18}$ Secara umum, dalam penulisan silsilah yang muncul selalu nama-nama lelaki. ${ }^{19} \mathrm{Hal}$ itu dianggap sebagai sesuatu yang wajar, oleh sebab itu narator cukup menyebut anak-anak Nuh saja.

Urutan nama anak-anak Nuh adalah: Sem, Ham dan Yafet, sesuai dengan yang tertulis dalam Kej.5:32; 6:10; 7:13 dan 10:1. Dari sini dapat dilihat bahwa Ham adalah anak yang kedua. Urutan ini akan mengalami perubahan pada ayat 24 dan harus diakui bahwa perubahan ini menimbulkan persoalan dan akan dibicarakan pada tafsiran terhadap ayat 24 nanti. Lempp menafsirkan bahwa, anak-anak Nuh ini merupakan wakil dan perwujudan dari seluruh umat manusia yang terbagi dalam 3 kelompok bangsa, Sem adalah bangsa yang menduduki Siria dan Palestina, Ham mewakili bangsa Afrika dan beberapa bangsa di Babel, Yafet adalah gelar untuk bangsa-bangsa yang mendiami wilayah Kerajaan hetit. ${ }^{20}$ Pendapat Lempp ini akan didiskusikan lebih dalam lagi pada bagian ketiga, yang membicarakan ayat 25-27.

Penjelasan narator tentang Ham adalah bapak/nenek moyang Kanaan ini pun mengundang permasalahan. Westermann, mengatakan bahwa penjelasan ini merupakan tambahan kemudian dari narator untuk meluruskan cerita yang dituangkan dalam ayat

Evangelical Theological Society, vol. 42 (USA:

Paternoster Press, 2000), 300.

19 Firman Panjaitan, "Memaknai Penyelamatan Zipora

Terhadap Rencana Pembunuhan Musa Oleh Tuhan,"

Bia': Jurnal Teologi Dan Pendidikan Kristen

Kontekstual 2, no. 2 (2019): 264-77,

https://doi.org/10.34307/b.v2i2.71.

${ }^{20}$ Longman III and Garland, "The Expositor's Bible Commentary." 
25. ${ }^{21}$ Bagi penulis, narator memang sengaja mencantumkan penjelasan tersebut sejak awal cerita, bahkan diulang lagi pada ayat 22, karena narator hendak menggiring pembaca pada satu kerangka pikir tentang tokoh Ham ini. Bahwa yang dimaksud dengan Ham adalah bapak Kanaan.22 Dengan demikian alur cerita menjadi jelas.

Setelah peristiwa air bah, Allah memberkati Nuh dan anak-anaknya agar memenuhi bumi. Berkat ini sejajar dengan berkat yang diberikan Allah pada Kej.1:28. Berkat yang terkait dengan keturunan.23 Proses penciptaan manusia kembali diperlukan dalam suasana yang baru dimana Allah berjanji tidak akan ada air bah lagi. Yang menarik adalah penduduk yang tersebar di seluruh bumi itu berasal dari satu keluarga, yaitu keluarga Nuh. Dengan kata lain, meskipun berbeda-beda (tempat dan keberadaannya) mereka semua terikat dalam satu persaudaraan. Westermann memertegas hal ini dengan pernyataan bahwa adanya penduduk di bumi dari satu keluarga yang diselamatkan dari air bah, sehingga umat manusia berada dalam satu kesatuan. ${ }^{24}$ Mereka manusia biasa, keturunan Nuh dan diceritakan sebagai orang yang hidup bergaul dengan Allah (Kej. 6:9).

\section{Episode 2: Kejadian 9:20-24}

Setelah narator membuka cerita dengan uraian tentang keturunan Nuh yang akan memenuhi bumi, narator mengarahkan pembaca pada masalah yang terjadi dalam keluarga Nuh yang nantinya mempengaruhi perkembangan selanjutnya, yang berbeda dengan uraian

\footnotetext{
${ }^{21}$ Singgih, Dari Eden Ke Babel: Sebuah Tafsir Kejadian 1-11.

22 Knust, "Who's Afraid of Canaan's Curse? Genesis 9:18-29 and the Challenge of Reparative Reading." 23 Firman Panjaitan, "Dialog Imajiner Kaum Tertindas: Tafsir Kejadian 3:1-6 Dalam Konsep Carnivalesque Bakhtin," Kenosis: Jurnal Kajian Teologi 6, no. 1 (2020): 1-22,

https://doi.org/https://doi.org/10.37196/kenosis.v6i1. 88.
}

dalam bagian pendahuluan. Pada bagian ini di awali dengan tokoh Nuh yang menjadi petani (dalam bahasa asli sebenarnya diterjemahkan dengan frasa 'manusia tanah'). Menurut Lempp, kesulitan yang muncul dalam terjemahan adalah: bila dikatakan Nuh adalah petani pertama, maka teks mengabaikan Adam dan Kain (Kej.3:17,19 dan Kej.4:2) yang telah lebih dahulu menjadi petani. ${ }^{25}$ Sedangkan Westermann mengungkapkan bahwa bila Nuh digambarkan sebagai seorang petani, bukan berarti bahwa ia adalah petani yang pertama, namun petani yang mengembangkan pengelolaan tanah yang lebih maju. ${ }^{26}$ Penulis lebih setuju menerjemahkan petani yang pertama, dalam konteks suasana baru sesudah air bah. Dengan demikian tidak mengabaikan Adam dan Kain, namun ingin menegaskan adanya sesuatu yang baru, yang berbeda. Dan hal ini diperjelas dengan adanya gambaran baru tentang tanah yang tidak menghasilkan duri dan onak, namun tanaman yang mendatangkan kesukacitaan yaitu anggur. Karena Nuh adalah petani pertama dalam konteks yang baru ini, maka ia juga yang pertama membuat kebun anggur, yang dikelola dengan sistem yang lebih maju. ${ }^{27}$ Anggur adalah jenis minuman yang dapat mendatangkan sukacita bahkan seringkali dipakai menjadi tanda berkat dalam kehidupan di jaman mesianik,28 namun demikian juga dapat berakibat buruk terhadap manusia, sebagaimana yang diungkapkan oleh narator dalam ayat selanjutnya

Dengan cepat narator mengisahkan tentang Nuh yang menikmati hasil kerjanya dan pada akhirnya Nuh menjadi mabuk. Ungkapan 'mabuk' dapat menimbulkan penilaian negatif,

\footnotetext{
24 Singgih, Dari Eden Ke Babel: Sebuah Tafsir Kejadian 1-11.

25 Bolin, "Noah's Curse: The Biblical Justification of American Slavery."

${ }^{26}$ Singgih, Dari Eden Ke Babel: Sebuah Tafsir Kejadian 1-11.

${ }^{27}$ Congrong Dai, "The Original Sin in Finnegans Wake,"

Neohelicon 39, no. 2 (2012): 475-83,

https://doi.org/10.1007/s11059-012-0146-9.

${ }_{28}$ Bolin, "Noah's Curse: The Biblical Justification of American Slavery."
} 
namun dalam hal ini tidak dapat begitu saja menilai tindakan Nuh sebagai sesuatu yang negatif, karena pada saat itu Nuh sedang terpesona dengan kenikmatan yang dihasilkan dari buah yang ditanamnya pertama kali. ${ }^{29}$ Ada kemungkinan Nuh belum tahu bahwa anggur dapat membuat orang menjadi mabuk, karena ada 2 pendekatan yang dapat dipakai dalam memahami teks ini, yaitu pendekatan etik, yang merupakan sebuah model peringatan akan akibat buruk minum anggur secara berlebihan dan pendekatan kultural yang melihat bahwa Nuh baru tahu potensi penemuan barunya pada saat itu. ${ }^{30}$

Dalam keadaan mabuk, Nuh telanjang di kemahnya. Telanjang merupakan aib dan ketelanjangan, dalam Perjanjian Lama, biasanya menunjuk pada kehilangan martabat sebagai individu maupun mahluk sosial. ${ }^{31}$ Dari kedua pernyataan ini, narator hendak mengungkapkan betapa dalamnya dampak minum anggur secara berlebihan, membuat manusia kehilangan kemampuan mengontrol diri. Lebih ironis lagi bila dibandingkan dengan Kejadian 6:9, bahwa Nuh adalah orang yang hidup bergaul dengan Allah. Dengan demikian ada perbedaan karakter dari Nuh yang hidup bergaul dengan Allah dengan Nuh yang sedang mabuk dan telanjang pada bagian ini.32 Menurut Penulis, narator dalam bagian ini bukan hanya hendak menekankan ketidaktahuan/keterpesonaan Nuh, namun sekaligus mengungkapkan betapa dalamnya dampak yang diakibatkan setelah minum anggur berlebihan. Hal ini dibuktikan dengan munculnya kata telanjang sebanyak satu kali dan ketelanjangan (LAI menerjemahkan

\footnotetext{
29 Alan P Ross, "The Table of Nations in Genesis 10-Its Content," Bibliotheca Sacra 138 (1981): 22-34.

$3^{\circ}$ E.G. Singgih, Dunia Yang Bermakna: Kumpulan Karangan Tafsir Perjanjian Lama (Jakarta: Persetia, 1999), 137; Karolien Vermeulen, "Verbal Creation: From Linguistic Feature to Literary Motif in Genesis 1-11," Scandinavian Journal of the Old Testament 31, no. 2 (2017),

https://doi.org/10.1080/o9018328.2017.1333768.

${ }^{31}$ Was Noah Good? : Finding Favour in the Flood

Narrative, Was Noah Good? : Finding Favour in the
}

dengan frasa 'aurat ayahnya') sebanyak tiga kali dalam ayat selanjutnya.

Kemudian Ham, bapak Kanaan, melihat ketelanjangan ayahnya. Kata 'melihat' (ra'ah) mempunyai arti: melihat, mendapat penglihatan, memandang dengan pandangan tertentu, melihat keadaan atau kegiatan tertentu, investigasi, inspeksi, mencari, mengunjungi, menyeleksi.33 Dari berbagai makna yang ada, memungkinkan adanya berbagai penafsiran terhadap tindakan Ham ini, bahwa ia bukan sekadar melihat, namun lebih jauh dari itu. Bahkan dalam pandangan yang cukup ekstrim, Bloom mengatakan bahwa Ham melakukan tindakan sodomi terhadap ayahnya.34 Tafsiran seperti ini,mendukung pernyataan yang mengatakan bahwa hukuman yang ditimpakan kepada Ham begitu berat. Tidak mungkin bila hanya karena sekadar melihat, lalu Ham dihukum menjadi hamba yang sangat rendah. Bila yang dilakukan Ham memang salah secara moral, maka hukuman yang diberikan pun harus seimbang. Pandangan ini dibantah oleh Gowan dan Westermann, yang mengatakan bahwa kata 'memandang/melihat' tidak bisa dilepaskan dari hal-hal lain yang mengikutinya, yaitu Ham keluar dari tenda, membiarkan ayahnya tetap telanjang, lalu membicarakan hal itu kepada saudarasaudaranya.

Tindakan membiarkan ketelanjangan ayahnya sangat tidak tepat, karena berarti penghinaan terhadap ayahnya.35 Di tempat lain, Singgih mengatakan bahwa kesalahan yang dilakukan Ham adalah memberitahukan hal

Flood Narrative, 2014, https://doi.org/10.5040/9780567659026.

$3^{2}$ Vermeulen, "Verbal Creation: From Linguistic Feature to Literary Motif in Genesis 1-11."

33 Eng, New International Dictionary of Old Testament Theology and Exegesis.

34 H. Bloom, The Book of $J$ (Great Britain: Faber and Faber Limited, 1991), 156.

35 Vermeulen, "Verbal Creation: From Linguistic Feature to Literary Motif in Genesis 1-11." 
ketelanjangan ayahnya kepada saudarasaudaranya, karena merupakan tindakan yang mempermalukan ayahnya, sehingga harus dihukum berat.36 Penulis tidak sependapat dengan para penafsir yang menafsirkan "melihat" sebagai tindakan hubungan seksual, baik dengan ibunya ataupun dengan ayahnya. Penulis lebih setuju dengan pendapat Westermann, karena sesuai dengan konteks cerita dan hal ini akan semakin jelas dalam ayat selanjutnya di mana tindakan Ham ini dilawankan dengan tindakan Sem dan Yafet.

Dalam ayat 23, narator mengisahkan tindakan Sem dan Yafet sebagai berikut: mereka mengambil pakaian, meletakkan di pundak, dan menutup ketelanjangan ayahnya tanpa melihat. Tindakan ini berbeda dengan tindakan Ham, yaitu: masuk ke tenda, melihat, (mungkin) tertawa atau heran, dan keluar untuk memberitahu saudara-saudaranya. Dari perbedaan ini tampak bahwa kesalahan Ham adalah melihat tetapi tidak menutup ketelanjangan ayahnya, bahkan memberitahukan pada saudara-saudaranya. Semua tindakan Sem dan Yafet yang tidak dilakukan oleh Ham adalah kesalahan. Karena seperti yang diuraikan pada bagian sebelumnya, bahwa ketelanjangan adalah simbol kerendahan martabat manusia, bila dibiarkan berarti penghinaan terhadap ayahnya yang seharusnya dihormati.37 Selanjutnya, dengan memberitahukan ketelanjangan itu kepada saudara-saudaranya di luar tenda, berarti tindakan Ham telah menyebarluaskan kerendahan atau kehinaan ayahnya. Dengan kata lain, Ham telah mempermalukan ayahnya di depan saudarasaudaranya dan mungkin juga didengar oleh anggota keluarga yang lain. Jadi tingkat kesalahan Ham berlapis-lapis dan sangat serius karena dilakukan terhadap ayahnya, kepala

\footnotetext{
${ }^{36}$ E.G. Singgih, Berteologi Dalam Konteks: PemikiranPemikiran Mengenai Kontekstualisasi Teologi Di Indonesia (Jakarta-Yogyakarta: BPK Gunung MuliaKanisius, 2000), 191.

37 Ross, "The Table of Nations in Genesis 10-Its Content."
}

keluarga yang mempunyai hak untuk dihormati dan memiliki kekuasaan yang lebih tinggi dari pada anggota keluarga lainnya.

Ayat 24 menjadi ayat yang bermasalah, karena dalam ayat itu dikatakan bahwa setelah Nuh sadar dari mabuknya, ia mengetahui apa yang dilakukan 'anak bungsunya' (yang paling muda) kepadanya. Teks ini merupakan teks yang sulit karena terjadi perubahan dari Ham sebagai anak kedua menjadi anak bungsu. Namun sebelum membahas hal ini, terlebih dahulu dibicarakan hal yang lain, yaitu tentang kata "mengetahui" (yada). Kata "mengetahui" ini memiliki beberapa pengertian juga, antara lain: observasi, menyadari, mencari jalan keluar, berhubungan dengan seksualitas, mengerti, mengetahui, yang semuanya itu diperoleh melalui intelektual, informasi, pengalaman, hikmat ataupun refleksi teologis. 38

Bagi penulis, Nuh dapat mengetahui apa yang dilakukan oleh Ham karena ia mendapatkan informasi dari keluarganya, meskipun teks ini tidak memerlihatkan dengan jelas dari mana Nuh mengetahui apa yang dilakukan oleh Ham. Karena, biasanya dalam komunitas kecil, halhal apapun bisa diketahui bersama, apalagi bila diingat bahwa Ham menceritakan ketelanjangan ayahnya di luar tenda (area umum). Jadi, tidak mungkin hanya Ham, Sem dan Yafet yang mengetahui. Narator juga mengisahkan hal ini dengan cepat, seolah-olah proses bagaimana Nuh mengetahui apa yang dilakukan Ham terhadap ayahnya, bukanlah hal yang penting. Agaknya yang dipentingkan justru bagaimana sikap menghormati orang yang lebih tua itu gagal dilakukan oleh Ham, padahal dalam penerusan generasi hal menghormati orang tua adalah tradisi yang sangat penting. 39

${ }^{38}$ Eng, New International Dictionary of Old Testament Theology and Exegesis.

39 Vermeulen, "Verbal Creation: From Linguistic Feature to Literary Motif in Genesis 1-11." 
Berikutnya, terkait dengan perubahan urutan Ham dalam keluarga, penulis sepakat dengan Davidson yang menjelaskan bahwa terjemahan 'anak laki-laki yang lebih muda' tidak dapat diterima secara ilmu bahasa, sehingga terjemahan yang lebih tepat adalah "anak yang termuda" atau bungsu. 40 Karena memang ada kenyataan urutan yang berbeda antara SemHam-Yafet dengan Sem-Yafet-Kanaan, maka para penafsir umumnya memberikan hipotesa bahwa ada dua tradisi berbeda yang disatukan dalam cerita ini. ${ }^{41}$ Tentu saja jawaban ini tidak memuaskan, apalagi bila ditempatkan dalam konteks cerita secara keseluruhan. Hal ini adalah persoalan pelik. Apakah narator sengaja melakukan hal ini atau tidak, penulis merasa sulit untuk menelusur kebenarannya. Yang pasti adalah, adanya pergeseran urutan anakanak Nuh karena adanya dua tradisi berbeda yang disatukan dalam peredaksian dan Ham, bapak Kanaan ditempatkan sebagai anak termuda.

Dalam episode kedua ini (Kej.9: 20-24), narator menceritakan tentang masalah penghinaan yang memermalukan orang tua (dilakukan oleh Ham, bapak Kanaan). Masalah ini muncul karena ketidaktahuan Nuh akan kekuatan anggur yang dapat memabukkan dan membuatnya tidak mampu mengontrol dirinya, sehingga pada akhirnya, tanpa disadari ia telah merendahkan martabatnya sendiri. Jadi kehidupan baru yang seharusnya diisi dengan peradaban baru ternyata tidak lepas dari tindakan tercela, sadar atau tidak sadar (yang dilakukan Nuh dan Ham). Kondisi ini dekat dengan Kejadian 8:21 yang mengungkapkan bahwa dalam diri manusia tidak hanya ada yang baik tapi juga ada yang jahat, dan hal ini sekaligus memerlihatkan bahwa dalam keluarga Nuh, sebagai keluarga yang sudah terseleksi, pun bisa terjadi.

\footnotetext{
${ }^{40}$ Robert J. V. Hiebert et al., Theological Dictionary of the Old Testament, Journal of Biblical Literature, vol. 119 (Michigan Cambridge, UK: Grand Rapids, 2000), https://doi.org/10.2307/3268510.

${ }^{41}$ Bolin, "Noah's Curse: The Biblical Justification of American Slavery"; Frankel, "Noah's Drunkenness and
}

\section{Episode 3: Kejadian 9:25-27}

Bagian ketiga dari cerita ini, merupakan puncak cerita, di mana didalamnya dikisahkan tentang kemarahan Nuh yang diungkapkan dalam bentuk hukuman bagi Ham atau lebih tepat bagi keturunan Ham..$^{2}$ Dalam teks, yang dihukum oleh Nuh adalah Kanaan. Ini menjelaskan bahwa narator sudah sejak awal menggiring pembaca pada pemahaman bahwa Ham adalah bapak Kanaan, sehingga meskipun hanya disebutkan Kanaan dalam ayat ini, sudah terlintas dalam pikiran bahwa yang dimaksud adalah Ham dan keturunannya.

Cukup menarik pula untuk dicermati, bahwa narator memakai kata 'Kanaan' ini sebanyak lima kali dalam perikop ini, dan kata 'Kanaan' ini menunjuk pada masyarakat (termasuk kebudayaannya) keturunan Ham yang kemungkinan besar tinggal di dataran rendah Palestina yang subur. Kemungkinan besar kata 'Kanaan' ini merupakan jenis national adage, yang memerlihatkan adanya tema dominasi satu kelompok terhadap kelompok yang lain. Hal ini dapat dimengerti dengan lebih jelas bila dikaitkan dengan kata eved (hamba) yang merupakan istilah teknis untuk subordinasi secara politis. Dengan demikian maka kata 'Kanaan' memerlihatkan ketundukan total dan pengabdian penuh orang-orang Kanaan terhadap kelompok yang lain. 43

Jadi, Ham yang melakukan kesalahan dihukum bersama seluruh keturunannya, menjadi hamba (eved) yang terendah (dengan ungkapan: hamba dari hamba-hamba saudara lakilakinya). Tampaknya hukuman ini tidak adil bila hanya dilihat sebagai akibat 'melihat', namun karena yang dilakukan bermakna penghinaan terhadap orang tua sekaligus tindakan yang mempermalukan, maka

the Curse of Canaan: A New Approach"; Dai, "The Original Sin in Finnegans Wake."

${ }^{42} \mathrm{H}$. Bloom, The Book of $J$.

43 Hiebert et al., Theological Dictionary of the Old Testament. 
hukuman ini menjadi seimbang. 44 Konsekuensi tindakan Ham adalah direndahkan begitu rupa di bawah saudara-saudaranya.45 Bila dilihat dari rumus berkat dan kutuk, kombinasi kata hayah (akan menjadi) dengan kata eved (hamba) dan le'ekhach (bagi saudaranya - ayat 25) melukiskan konsekwensi dari berkat atau kutuk.46 Jadi kutuk yang diucapkan oleh Nuh (figur yang lebih berkuasa) benar-benar menempatkan Kanaan, pada status yang sangat rendah. Dari sini dapat dilihat bahwa narasi ini memunculkan pola: karena Ham merendahkan Nuh maka ia direndahkan. Jadi ada model pembalasan yang juga muncul pada zaman baru, sesudah air bah. Kanaan menjadi lambang dari 'ketidaksopanan' atau 'penghinaan terhadap orang tua', sehingga Kanaan pun patut direndahkan, bahkan ditempatkan sebagai hamba yang terendah, hidup dalam ketundukan total dibawah saudara-saudaranya. Peristiwa ini menjadi dasar pembenaran bagi Israel untuk menyerbu dan menundukkan orang-orang Kanaan. 47

Selanjutnya, siapa yang dimaksud dengan Sem dan Yafet dalam cerita ini juga menimbulkan ketidak jelasan. Pada penjelasan awal dipahami bahwa Sem adalah bangsa-bangsa yang memasuki Palestina pada masa perjalanan bangsa-bangsa Aram, sedangkan Yafet adalah bangsa-bangsa yang berkedudukan di utara, di daerah Kerajaan Hetit. ${ }^{8}$ Namun penjelasan ini hanyalah salah satu dari sekian banyak kemungkinan yang sulit untuk dipastikan secara historis. Teks sendiri memberi gambaran yang tidak terlalu jelas, misalkan: dalam pujian terhadap Sem, disebut tentang TUHAN, Allah Sem, yang bisa ditafsirkan bahwa Sem adalah Israel, sedangkan Yafet diam/tinggal bersama keturunan Sem, apakah hal itu bisa ditafsirkan bahwa, Yafet adalah orang Filistin.49 Jadi

\footnotetext{
44 Bolin, "Noah's Curse: The Biblical Justification of American Slavery."

45 Vermeulen, "Verbal Creation: From Linguistic Feature to Literary Motif in Genesis 1-11."

${ }^{46}$ Hiebert et al., Theological Dictionary of the Old Testament.
}

menurut penulis, cerita ini tidak hendak menggambarkan siapa bangsa-bangsa yang dimaksud sebagai keturunan Sem dan Yafet secara pasti, sebagaimana umumnya ditafsirkan, namun penulis memandang bahwa narator hendak melukiskan kesungguhan hukuman terhadap Ham dan keturunannya. Bahwa mereka akan menjadi hamba bagi saudara-saudaranya (diungkapkan sebanyak tiga kali dalam rumusan kutuk). Yang diberkati (Sem dan Yafet) menjadi tuan, sedangkan Ham yang dihukum menjadi hamba yang mengabdikan diri pada tuannya. Ini adalah perubahan penting yang terjadi sebagai wujud kemarahan Nuh. Kemarahan Nuh, yang menggambarkan tentang keretakkan hubungan Nuh dan Ham, meretakkan hubungan antar saudara. Apakah hal ini tidak berarti berdampak dalam kehidupan sosial? Tentu saja keretakan antar pribadi dapat menjadi sumber keretakan hubungan sosial dalam komunitas yang lebih luas.

Dalam bagian ketiga ini, narator hendak mengungkapkan akibat dari bagian kedua yang harus ditanggung oleh Ham, bapak Kanaan, sekaligus hadiah bagi Sem dan Yafet yang bertindak benar menurut konteks cerita. Selain itu narator juga memerlihatkan adanya keretakan hubungan dalam keluarga, akibat terbentuknya pola balas dendam, yang berdampak pada keturunan semua pihak. Yang menarik dari episode ini adalah: peristiwa ini terjadi pada zaman baru, yaitu sesudah air bah, di dalam keluarga Nuh yang telah menjadi keluarga yang terseleksi.

\section{Episode 4: Kejadian 9:28-29}

Setelah sampai pada klimaks cerita di bagian ketiga, terjadi pemutusan alur cerita. Di episode keempat ini narrator, mendadak, memberikan
47 Singgih, Dunia Yang Bermakna: Kumpulan Karangan Tafsir Perjanjian Lama.

${ }^{48}$ Vermeulen, "Verbal Creation: From Linguistic Feature to Literary Motif in Genesis 1-11."

49 Mathee, "Curse Motives in the 'Curse of Ham' Narrative: Land for Yahweh'S Landless People?" 
informasi tentang umur Nuh yang mencapai 950 tahun. Bagian ini lebih tepat diterima sebagai penutup seluruh narasi tentang air bah, karena merupakan kelanjutan dari kisah dalam Kejadian 5:32. Dari pemutusan alur ini, agaknya narator ingin mengungkapkan bahwa tragedi dalam keluarga Nuh yang pada akhirnya menjadi tragedi yang dilestarikan oleh keturunan Nuh adalah suatu kebenaran dalam sejarah kehidupan manusia selanjutnya.

\section{Relevansi}

Dari kesimpulan yang diperoleh tampak bahwa apa yang diungkapkan dalam Kejadian 8:15-9: 17, sebagai latar belakang dekat dari kisah Kejadian 9:18-29, terwujud dalam kehidupan keluarga Nuh. Namun hal ini bukan hanya terjadi dalam keluarga Nuh saja tetapi juga terjadi pada kehidupan masa kini. Hal ini tampak dalam beberapa peristiwa, antara lain, pertama, semangat persaudaraan yang seharusnya ada dalam kehidupan manusia sebagai satu komunitas yang utuh telah mengalami masa krisis panjang. Tradisi memandang saudara sebagai 'orang lain', karena perbedaan-perbedaan yang ada telah semakin kuat mewarnai kehidupan masa kini. Hal ini tampak dalam berbagai aspek kehidupan. Dalam lingkup keluarga, masingmasing anggota keluarga sibuk dengan diri dan dunianya sendiri sehingga hubungan satu dengan yang lain menjadi asing. Kepedulian untuk saling memperhatikan, saling membantu layaknya hubungan persaudaraan telah pudar. ${ }^{\circ}$ Dalam lingkup masyarakat yang lebih luas krisis persaudaraan sangat nyata dengan adanya jurang antara yang kaya dan yang miskin, ketegangan antar umat beragama, ketegangan antar partai politik dan konflikkonflik antar ras/suku bangsa. Narasi ini menjadi kritik terhadap kehidupan pada masa kini, yang mengingatkan kembali bahwa sebagai umat manusia pasca air bah,

50 Mardiharto Mardiharto, "Pola Asuh Pendidikan Kerohanian Pada Anak," PASCA : Jurnal Teologi Dan Pendidikan Agama Kristen 15, no. 1 (2019): 23-27, https://doi.org/10.46494/psc.v15i1.65. perbedaan bukanlah dasar untuk menodai persaudaraan antar manusia. Justru nilai persaudaraan harus dilestarikan dalam kerangka menjadi manusia dalam era baru. Orang lain bukanlah 'orang lain', orang lain adalah saudaraku.

Kedua, kesediaan Allah menerima keberadaan manusia apa adanya, yaitu manusia yang memiliki potensi baik dan buruk. Di dalam dirinya manusia memiliki kemampuan untuk berbuat baik dan jahat. Oleh sebab itu manusia harus menyadari keberadaannya, sadar akan batas-batasnya serta terbuka untuk bersikap kritis terhadap diri sendiri. Memang benar bahwa gambaran ideal, yaitu setelah air bah kehidupan menjadi baik, belum terwujud sampai saat ini bahkan sulit untuk diwujudkan, namun tidak berarti bahwa tidak perlu ada upaya mewujudkan kehidupan yang baik. Justru ketika manusia sadar akan keberadaannya dan terbuka untuk bersikap kritis terhadap diri sendiri, maka peluang terciptanya kehidupan yang baik semakin besar. ${ }^{51}$ Melalui keluarga Nuh ini manusia diajak untuk menyadari keberadaan dirinya dan diajak untuk selalu terbuka terhadap diri sendiri demi kehidupan bersama yang lebih baik, bukan dasar untuk memanfaatkan ketidak sempurnaan manusia sebagai legitimasi tindak kejahatan manusia.

Ketiga, peradaban baru yang diciptakan oleh manusia selalu mempunyai dua sisi, baik dan buruk, misalnya teknologi modern, di satu sisi memercepat kerja manusia, namun di sisi lain membuat jumlah pengangguran meningkat, dan masih banyak contoh yang lain. Berangkat dari ketidak sempurnaan manusia, maka apa yang dihasilkannya pun juga tidak sempurna. Narasi ini mengajak dan mengajarkan untuk memahami bahwa peradaban yang diciptakan oleh manusia selain meningkatkan taraf hidup, juga dapat menjadi ancaman yang

${ }^{51}$ Djoko Sukono, “Teologi ‘Manusia Baru' Relevankah Di Era Milenial," PASCA : Jurnal Teologi Dan Pendidikan Agama Kristen 15, no. 2 (November 29, 2019): 39-44, https://doi.org/10.46494/psc.v15i2.59. 
merendahkan harkat dan martabat bahkan menghancurkan diri dan relasi antar manusia, manusia dan lingkungannya, sebagaimana ketelanjangan yang dialami oleh Nuh, sebagai akibat keterpesonaannya pada anggur. Dengan didasarkan atas pemahaman tersebut, dapatlah dikatakan bahwa peningkatan peradaban yang diciptakan manusia harus diiringi dengan kesadaran moral dalam diri manusia, sehingga peningkatan peradaban akan membawa manusia pada tatanan kehidupan yang lebih baik.

Keempat, menghormati orang tua, menjaga nama baik dan kehormatan orang tua adalah ajaran yang diwariskan turun temurun oleh bangsa manapun di dunia ini. Budaya apapun memertahankan ajaran ini karena diakui bahwa orang tua adalah pemegang otoritas tertinggi dalam keluarga, meskipun dalam budaya patriakhal, yang dimaksud dengan orang tua ini adalah ayah/bapak. $5^{2}$ Namun demikian, ajaran tersebut tidak selalu dapat dihayati dengan baik, sebagaimana yang dilakukan oleh Ham dalam narasi di atas. Kecenderungan untuk melawan dan tidak menjaga kehormatan orang tua, secara umum dialami oleh anak-anak pada masa puber, bahkan pada masa post-modernisme ini banyak anak muda yang ingin melepaskan diri dari ikatan ajaran ini. Narasi ini secara kritis memperlihatkan bahwa ada hubungan yang erat antara tindakan menghormati orang tua dan tindakan orang tua itu sendiri. Jadi menurut penulis, narasi ini berbicara bagi kedua belah pihak, yaitu anak dan orang tua. Bagi anak, menghormati orang tua dan menjaga nama baik/kehormatan orang tua adalah kewajiban yang harus dilakukan dengan tulus dan penuh cinta kasih, dengan menyadari bahwa orang tuapun memiliki keterbatasan, sekaligus kesadaran bahwa orang tua adalah

\footnotetext{
${ }^{2}$ Firman Panjaitan, "Kekerasan Terhadap Istri Dalam Lingkup Domestik (Suatu Tinjauan Etis Kristiani Tentang Kekerasan Terhadap Keluarga)," Fidei: Jurnal Teologi Sistematika Dan Praktika 1, no. 1 (2018): 4267, https://doi.org/10.34081/fidei.vii1.3.

53 Firman Panjaitan, "Membangun Nisbah Kehidupan Rumah Tangga: Tafsir Kolose 3:18-4:1,” GEMA
}

bagian dari keluarga yang tidak dapat diabaikan begitu saja. Bagi orang tua, juga harus berusaha untuk menjaga diri sehingga dapat menjadi teladan bagi anak, sadar akan keterbatasannya dan menerima keberadaan anak dan dunianya yang berbeda dengan dunia orang tua. 53

Kelima, labelisasi terhadap Kanaan yang pada akhirnya menjadikan Kanaan sasaran penyerbuan atau penindasan, menurut penulis perlu direnungkan kembali.54 Narasi ini memang berbicara tentang hal itu, namun apakah hal itu layak untuk dipertahankan? Bukankah dampak yang dihasilkan adalah penderitaan bagi Kanaan yang juga adalah saudara? Bukankah tindakan tersebut merupakan bentuk ketidakadilan? Apakah di luar orang Kanaan lebih baik hidupnya (termasuk moralitasnya), dari pada orang Kanaan? Menurut penulis, narasi ini justru harus dipakai secara reflektif agar tercipta kehidupan bersama yang dipenuhi dengan persaudaraan, bukan dasar untuk melakukan labelisasi secara negatif terhadap bangsa/golongan/kelompok/jenis kelamin tertentu. Apakah layak manusia terus menerus menghukum sesamanya melalui proses pelestarian labelisasi?

Keenam, pola dominasi dan pembalasan adalah bagian dari sejarah kehidupan manusia, hingga saat ini. Dominasi ini terjadi antar saudara, antar bangsa, antar kelompok, antar jenis kelamin antar kelas dalam masyarakat dan antar generasi. Demikian juga halnya dengan pola pembalasan, bahkan dalam beberapa budaya, tradisi ini dilestarikan (misalnya: suku Madura, Dayak, Toraja). Pola dominasi dan pembalasan telah melahirkan banyak penderitaan dalam kehidupan dan luka-luka yang diakibatkan tidak mudah untuk disembuhkan.55 Proses rekonsiliasi yang

TEOLOGIKA: Jurnal Teologi Kontekstual Dan Filsafat Keilahian 6, no. 1 (2021): 81-94,

https://doi.org/10.2146o/gema.2021.61.659.

54 Dai, "The Original Sin in Finnegans Wake."

55 Firman Panjaitan, "Stop Kekerasan: Tafsir Kejadian 4:17-26," Academia Edu, 
diupayakan seringkali mengalami hambatan baik secara internal maupun eksternal, karena manusia dan pola kehidupan yang diciptakannya telah membentuk manusia begitu rupa. Ikatan antara karakter dan sistem telah melestarikan pola dominasi dan pembalasan. Tragedi dalam keluarga Nuh memang telah menjadi tragedi bagi keluarga umat manusia pada masa kini. Hal ini merupakan kenyataan yang sangat memrihatinkan. Bagi penulis, tragedi ini seharusnya menjadi cermin yang membuat manusia masa kini menjadi malu, sedih dan sadar akan keberadaannya. Seharusnya tragedi ini dihentikan, karena meniadakan potensi baik dalam diri manusia. Seolah-olah manusia tidak mempunyai kemampuan untuk berbuat baik sama sekali. Seolah-olah manusia hanya bisa menciptakan penderitaan bagi dirinya dan lingkungannya. Tragedi ini harus dihentikan, ditransformasi menjadi kisah kehidupan yang di dalamnya ada persaudaraan, kesetaraan, keadilan, penghormatan dan keterbukaan.

\section{Kesimpulan}

Dari uraian di atas dapat disimpulkan bahwa zaman baru, sesudah air bah, yang dimulai melalui keluarga Nuh yang pada akhirnya tersebar ke seluruh bumi. Meskipun masingmasing memiliki perbedaan, namun mereka diikat dalam satu persaudaraan. Dalam zaman baru tersebut, Nuh dan keturunannya digambarkan sebagai manusia biasa, yang memiliki kelemahan dan kelebihan, sehingga zaman yang barupun tidak selalu dipenuhi dengan gambaran-gambaran ideal saja. Peradaban baru yang diciptakan oleh Nuh dan keluarganya, di satu sisi memerlihatkan hal yang positif, yaitu anggur yang mendatangkan sukacita, namun di sisi yang lain dapat menimbulkan hal yang negatif, yaitu kemabukan yang dapat melahirkan ketelanjangan (simbol kerendahan martabat manusia). Kesalahan fatal yang dilakukan oleh Ham adalah kegagalannya untuk menghormati dan mengembalikan martabat orang tuanya. Sehingga Kanaan (keturunan Ham) menjadi simbol ketidaksopanan atau penghinaan terhadap orang tua. Akibat kesalahan yang dilakukan Ham, maka terjadi perubahan pola hubungan antara orang tua dan anak, anak dan anak yang semula diwarnai dengan suasana kesatuan menjadi suasana dominasi, yang diberkati menjadi tuan dan yang dihukum menjadi hamba yang terendah. Sedangkan antara orang tua dan anak tercipta pola saling membalas (karena merendahkan, maka Ham direndahkan).

Narasi tentang Tragedi keluarga Nuh ini mempunyai makna yang sangat dekat dengan kehidupan pada masa kini. Tragedi ini mengajarkan hal-hal yang baik sekaligus menjadi cermin, yang menampakkan wajah dan kehidupan manusia masa kini. Namun bermakna atau tidaknya tragedi keluarga Nuh ini, tetap berpulang pada nurani setiap manusia. Ketika ada keterbukaan untuk memahami tragedi ini, peluang terjadinya perubahan selalu ada.

\section{Referensi}

Biblia 001-VT. Biblia Hebraica. Stuttgart: Deutsche Bibelgesellschaft, 1990.

Bolin, Thomas M. "Noah's Curse: The Biblical Justification of American Slavery." History: Reviews of New Books 31, no. 2 (2003): 61. https://doi.org/10.1080/03612759.2003.1052 7895 .

Dai, Congrong. "The Original Sin in Finnegans Wake." Neohelicon 39, no. 2 (2012): 475-83. https://doi.org/10.1007/s11059-012-0146-9.

Eng, Milton. New International Dictionary of Old Testament Theology and Exegesis. Journal of the Evangelical Theological Society. Vol. 42. USA: Paternoster Press, 2000.

Fisher, Don L. Hermeneutik Interpreting The 
Bible. Malang: Gandum Mas, 2016.

Frankel, David. "Noah's Drunkenness and the Curse of Canaan: A New Approach." Journal of Biblical Literature, 2021. https://doi.org/10.15699/JBL.1401.2021.3.

Friedman, Bruce D. "Noah: A Story of Peacebuilding, Nonviolence, Reconciliation, and Healing." Journal of Religion and Spirituality in Social Work 38, no. 4 (2019): 401-14.

https://doi.org/10.1080/15426432.2019.1672 609.

H. Bloom. The Book of J. Great Britain: Faber and Faber Limited, 1991.

Hiebert, Robert J. V., G. Johannes Botterweck, Helmer Ringgren, and Heinz-Josef Fabry. Theological Dictionary of the Old Testament. Journal of Biblical Literature. Vol. 119. Michigan Cambridge, UK: Grand Rapids, 2000. https://doi.org/10.2307/3268510.

Ibita, Ma Maricel S. "The Great Flood in Genesis 6-9: An Ecological Reading of the J and P Traditions." Biblical Theology Bulletin 50, no. 2 (2020): 68-76. https://doi.org/10.1177/0146107920913791.

Knust, Jennifer. "Who's Afraid of Canaan's Curse? Genesis 9:18-29 and the Challenge of Reparative Reading." Biblical Interpretation, 2014. https://doi.org/10.1163/1568515202245po2.

Leni Novita. "Pengaruh Kualitas Lingkungan Keluarga Dan Sekolah Terhadap Karakter Remaja Perdesaan." Sekolah Pascasarjana Institut Pertanian Bogor. Pascasarjana Institut Pertanian Bogor, 2016.

Longman III, Tremper, and David E. Garland. "The Expositor's Bible Commentary." In The Expositor's Bible Commentary Revised Edition, 2007.

Mardiharto, Mardiharto. "Pola Asuh Pendidikan Kerohanian Pada Anak." PASCA : Jurnal Teologi Dan Pendidikan Agama Kristen 15, no. 1 (2019): 23-27. https://doi.org/10.46494/psc.v15i1.65.

Mathee, Mohamed Shahid. "Curse Motives in the 'Curse of Ham' Narrative: Land for Yahweh'S Landless People?” Journal for Semitics 25, no. 2 (2017): 726-47. https://doi.org/10.25159/1013-8471/2554.

Nugroho, Widhi Arief. "Peranan Pendidikan Keluarga Tentang Kekudusan Hidup Menurut Roma 12:1-2." FIDEI: Jurnal Teologi
Sistematika Dan Praktika 1, no. 2 (2018): 185-98. https://doi.org/10.34081/fidei.v1i2.16.

Panjaitan, Firman. "Dialog Imajiner Kaum Tertindas: Tafsir Kejadian 3:1-6 Dalam Konsep Carnivalesque Bakhtin.” Kenosis: Jurnal Kajian Teologi 6, no. 1 (2020): 1-22. https://doi.org/https://doi.org/10.37196/ken osis.v6i1.88.

-_-. "Kekerasan Terhadap Istri Dalam Lingkup Domestik (Suatu Tinjauan Etis Kristiani Tentang Kekerasan Terhadap Keluarga).” Fidei: Jurnal Teologi Sistematika Dan Praktika 1, no. 1 (2018): 42-67. https://doi.org/10.34081/fidei.v1i1.3.

-_-. "Memaknai Penyelamatan Zipora Terhadap Rencana Pembunuhan Musa Oleh Tuhan." Bia': Jurnal Teologi Dan Pendidikan Kristen Kontekstual 2, no. 2 (2019): 264-77. https://doi.org/10.34307/b.v2i2.71.

- - . "Membangun Nisbah Kehidupan Rumah Tangga: Tafsir Kolose 3:18-4:1." GEMA TEOLOGIKA: Jurnal Teologi Kontekstual Dan Filsafat Keilahian 6, no. 1 (2021): 81-94. https://doi.org/10.21460/gema.2021.61.659.

-_- "Stop Kekerasan: Tafsir Kejadian 4:17-26." Academia Edu, n.d.

Rachman, Lutfi. "Peran Orang Tua Terhadap Anak Perspektif Pendidikan Islam.” Jurnal Pendidikan Islam 7, no. 02 (2017): 1-12. https://doi.org/10.38073/jpi.v7io2.41.

Rijali, Ahmad. "Analisis Data Kualitatif." Alhadharah: Jurnal Ilmu Dakwah 17, no. 33 (2019): 81-95. https://doi.org/10.18592/alhadharah.v17i33.2 374 .

Ross, Alan P. "The Table of Nations in Genesis 10Its Content." Bibliotheca Sacra 138 (1981): 22-34.

Singgih, E.G. Berteologi Dalam Konteks: Pemikiran-Pemikiran Mengenai Kontekstualisasi Teologi Di Indonesia. Jakarta-Yogyakarta: BPK Gunung MuliaKanisius, 2000.

---. Dari Eden Ke Babel: Sebuah Tafsir Kejadian 1-11. Yogyakarta: PPST UKDW, 2011.

---. Dunia Yang Bermakna: Kumpulan Karangan Tafsir Perjanjian Lama. Jakarta: Persetia, 1999.

Sukono, Djoko. “Teologi 'Manusia Baru' Relevankah Di Era Milenial.” PASCA : Jurnal Teologi Dan Pendidikan Agama Kristen 15, 
no. 2 (November 29, 2019): 39-44.

https://doi.org/10.46494/psc.v15i2.59.

Surip, Stanislaus. "Kelola Bumi Peduli Ekologi Menurut Kej 1:28.” Studia Philosophica et Theologica 20, no. 1 (2020): 80-99.

https://doi.org/10.35312/spet.v20i1.190.

Susanto, Herry. "The Church as God's People and The Patner of State." Jurnal Jaffray 17, no. 1 (2019): 35-56.

Syahroni, Sariwandi. "Peranan Orang Tua Dan Sekolah Dalam Pengembangan Karakter Anak Didik." Intelektualita 6, no. 1 (2017): 13. https://doi.org/10.19109/intelektualita.v6i1.1 298.

Vermeulen, Karolien. "Verbal Creation: From Linguistic Feature to Literary Motif in Genesis 1-11." Scandinavian Journal of the Old Testament 31, no. 2 (2017). https://doi.org/10.1080/09018328.2017.1333 768.

Was Noah Good? : Finding Favour in the Flood Narrative. Was Noah Good? : Finding Favour in the Flood Narrative, 2014. https://doi.org/10.5040/9780567659026.

Zaluchu, Sonny Eli. Pentateuch - Narasi Narasi Utama Kitab Musa. 1st ed. Semarang: Golden Gate Publishing, 2020. 